\title{
Using the Achimovka Technique in the Oil Industry as One of the Modern Ways of Increasing the Competitiveness of the Russian Federation in the World Market
}

\author{
Violetta Kuzmina ${ }^{1 *}$ \\ ${ }^{1}$ Southwest State University, 94, 50 Let Oktyabrya str., Kursk, 305040, Russian Federation
}

\begin{abstract}
The relevance of this study lies in the fact that the modern oil market is characterized by instability and high competition. Depletion of oil fields, deterioration of equipment for oil production, price volatility and political conflicts negatively affect Russia's position in the global energy market. New economic conditions in 2021 are associated with a decrease in demand for oil and oil products, high import dependence, conservation wells to complete the deal under OPEC ++, which will lead to a fall in the market by $3-10 \%$. It is necessary to apply new methods of oil production, one of which is the method of achimovka oil fields. Methods. The initial materials were statistical data from the Center for Macroeconomic Analysis and Short-Term Forecasting, the Ministry of Economic Development of Russia, the Analytical Center for the Government of the Russian Federation, world rating reports.

Results. The pandemic and self-isolation of 2020 led to the fact that the Russian oil sector lost $50-60 \%$ of proceeds from the export of hydrocarbons, more than $50 \%$ of its capitalization. To support the industry, the Ministry of Industry and Trade of Russia will allocate 35 billion rubles. until 2024 for the development of new offshore and deep oil deposits.

Conclusions. For Russian oil companies, the following is relevant: search for new sales markets (for example, Asia); application of innovative technologies to maintain the profitability of oil and gas production through the development of bazhen and achimovka; development of small deposits and deposits with hard-to-recover reserves.
\end{abstract}

\section{Introduction}

Actuality of the problem. In the second half of 2020, a tough competition unfolded on the world oil market, associated with a change in the pricing policy for this type of product. At the same time, China and India occupied these niches in energy imports. The increase in oil production and supplies from Iraq was an indicator that Saudi Arabia by 2020 was unable to play the role of a stabilizing energy producer.

\footnotetext{
*Corresponding author: kuzmina-violetta@yandex.ru
} 
The most powerful Russian companies Lukoil, Tatneft, Sibur Holding, Gazprom, Rosneft function quite effectively in the oil complex, but this is not enough for international competition. To strengthen Russia's position in the oil sector, the country's leadership has relied on high-tech and innovative development of the energy sector. First of all, this is the reception of oil production using hydraulic fracturing in the Achimov deposits, which are rich in all of Western Siberia.

The volume of publications on the oil and gas market is quite large.Foreign researchers first of all point to a problem that has worsened during the pandemic: this is a change in the dynamics of consumed oil and gas resources. First, there is a clear tendency of changing the place of developing countries in the structure of consumed energy consumption at the expense of oil and gas. This idea can be traced in a study by Andrea Gatto, who analyzed the World Bank's World Development Indicators (WDI), The Freedom House on the example of 37 oil-producing developing countries and countries with economies in transition from 1989 to 2019 [1].

Second, the transformation of the global energy system raises critical questions for many of the largest oil and gas producing countries. International climate policy and advances in low-carbon technologies can indeed exert sustained pressure on development models that rely heavily on hydrocarbon revenues. This trend is noted by Simone Tagliapietra for the countries of the Middle East and North Africa [2].

Third, there is a shock state in the world oil market (Mohammed Naif Alotaibi) [3]. Zekeriya Yildirim and Arif Arifli proved that a negative oil price shock worsens the trade balance, causes currency depreciation, increases inflation and reduces economic activity [4].

Sławomir Śmiech, Monika Papież, Michał Rubaszek, Małgorzata Snarska showed in the study that shocks of uncertainty in oil prices lead to a persistent drop in industrial production, which is not uniform in its depth in all analyzed countries. This reaction will be lasting only in the case of developing countries, Mexico and Russia [5].

A similar study was conducted by Russian and Greek experts and proved that positive shocks in oil prices had a positive and statistically significant impact on almost all types of economic activity in Russia (Svetlana Balashova and Apostolos Serletis) [6].

Fourthly, the struggle between IOCs and NOCs in the oil and gas market has intensified in modern conditions. Europe and North America are the most active regions for crossborder oil and gas mergers and acquisitions. The most active participants include the United States and Canada in North America, as well as the United Kingdom, the Netherlands, France, Switzerland and Russia in Europe (YueGuo, YuYang, ChangWang) [7].

Fifth, the current forecast of the development of global and national companies in the oil and gas sector indicates the need for a transition to an energy efficiency policy at the global and national levels (Marina Yesica Recalde) [8], Researchers (Longxin MU, Zhifeng JI) talk about the need to constantly develop traditional onshore oil and gas exploration methods for overseas exploration and maintain them at the forefront of the international level [9].

Thus, the analysis of the literature made it possible not only to identify current trends in the world oil and gas market, but also to find out that the activities of Russian oil and gas companies are poorly represented in the studies of foreign experts.

\section{Materials and Methods}

Methodology. The initial materials were statistical data from the Center for Macroeconomic Analysis and Short-Term Forecasting, the Ministry of Economic Development of Russia, the Analytical Center under the Government of the Russian Federation, and world rating reports. Secondary data sources are represented by World Bank data for 2019 [10] (World 
Development Indicators Database), Eurostat-OECD PPP Program [11], CPIA database [12].

Standard methods of statistical data processing were used with their subsequent analytical substantiation.

\section{Results}

The Russian oil and gas sector is represented by various large financial and industrial groups and small oil groups, each of which has its own dynamics of development under the influence of global and regional trends in this area of energy consumption.

Annually, the Russian Federation produces about 550 million tons of oil, and immediately almost half of the oil produced is refined. Russia is confidently holding on to the leading second place in terms of oil production after Saudi Arabia. This situation was largely facilitated by the US sanctions policy against Iran and Venezuela, which led to an increase in crude oil supplies in January-November 2019 by 3.8\%, according to the Federal Customs Service of the Russian Federation.Since 2018, the Russian fuel and energy complex has shown positive production and export dynamics. For comparison, in 2018, Russia exported 260.2 million tons of crude oil, which was $2.9 \%$ or 7.4 million tons more than in 2017 .

The main buyers of energy from Russia are countries such as the Netherlands, China, Germany, South Korea, Poland, Japan, Italy, Belarus, Turkey, Finland. According to the Ministry of Economic Development of the Russian Federation, Turkey has shown an increase in oil imports from Russia. Thus, in 2019, compared to the same period in 21018, the export of Russian crude oil to Turkey increased 4.5 times, since a number of Turkish oil refining industries changed their orientation from Western supplies to Russian raw materials [13].

Among domestic oil exporters, Lukoil stands out as it produces $2.2 \%$ of the world's oil. The share of this company in Russia accounts for $16.6 \%$ of all oil production [14]. OAO TATNEFT accounts for $8 \%$ of all oil production in Russia and $80 \%$ in Tatarstan.

Less well-known, but no less significant in the gas and oil industry of Russia is the Sibur Holding. One of the largest Russian holdings controlling 96\% of the oil and gas processing industry is the TAIF group of companies.

Apart from large companies, small oil companies occupy a significant place in the extraction and production of oil and oil products. There are about 160 of them, but all together they develop and produce oil at 160 fields in 23 regions of the Russian Federation [15]. These are the well-known companies Sibir Energy PLC, Urals Energy, PLCOOO Severnoye Siyanie, Lundin Petroleum and others. Geographically, these companies are based on the territory of Bashkortostan and Tatarstan.

Global trends in the oil and gas sector are characterized by a reaction to crises, changes in the price of a barrel of oil, and a decline in production over some years from 2008 to 2019. Russian companies showed a different trend. A. Bondar (A. Bondar, 2019) in his research notes that Russia has strengthened its position in the world oil market [16]. But R. Ivanov (2019) believes that not everything is so optimistic for our country, considering that Russia is far from leading positions in the world oil market [17].

In 2020, there was a rollback to production volumes and oil sales 2017-208Losses of the oil and gas sector accounted for 50-60\% of revenue from hydrocarbon exports and more than $50 \%$ of its capitalization [18].

Experts cite data on losses in capitalization - over 5 trillion rubles, or about $\$ 70$ billion. If we compare the quotes above \$ 75 per barrel in April 2019, then in 2020 they dropped below $\$ 16$ a year later due to the fall in energy consumption [19]. Rosneft in the first half of 2020 had a loss of 113 billion rubles, Lukoil - a loss of 64.7 billion rubles, Gazprom's net 
profit fell 25 times, falling to 33 billion rubles. Experts believe 2020 was the worst year for the Russian oil and gas sector.

\section{Discussion}

New technologies and communication opportunities, among other things, change the place of an employee in production, including in oil and gas production. The introduction of information technology leads to a reduction in human participation in production processes, and in fact we get qualified employees involved in remote monitoring and setting parameters. In turn, the development of mobile applications allows us to talk about future changes in the very principle of decision-making: the opinion of not one specialized specialist, but a multidisciplinary expert community will play the main role.

Despite some progress of Russian companies in introducing new technologies into production and the production of oil and gas, in general, the domestic oil and gas industries do not have full-fledged platforms for joint cooperation with other world companies using the latest IT technologies, but there are certain shifts in this direction. Thus, Gazprom Neft has created a Competence Center, which includes geologists, developers, seismologists from the Scientific and Technical Center, the corporate center and its subsidiaries [18].

For the first time, this Center began to work on the GeoMate platform ( information system), developed with the participation of experts from STC Gazpromneft and IT specialists of the company. However, today Gazprom Neft is just beginning to master all the possibilities of modern information technologies.

Analysts at VTB Capital gave an estimate of the decrease in EBITDA of the largest Russian oil companies in 2021 to \$ 39 billion, although their earlier forecast in January 2020 hovered around \$ 66 billion. Investbank analysts agree with them, who believe that as a result of lower prices for a barrel of oil, the Russian oil sector will lose \$24 billion in EBITDA in 2020 and \$ 12 billion in 2021.

Petroleum products in Europe. According to this indicator, VTB Capital experts estimate the losses of Russian oil companies at \$ 2 billion in EBITDA in 2020 and \$ 4 billion in 2021. The international rating agency Moody's expresses hope for the stabilization of prices per barrel of oil, which will lead to a halt in the unprofitable activity of the Russian oil and gas complexes [19].

Gas prices have shown negative dynamics since November 2019, in March 2020, cubic meters gas fell in price by almost half from \$ 0.29 to \$ 0.15. IEA experts believe that the planned under-consumption of gas in 2020 amounted to 150 billion cubic meters, that is, $4 \%$ of world production. Previously, such indicators have never been recorded for this industry. Analysts of the Ministry of Energy of the Russian Federation expect a recovery in global gas demand in the near future [18].

Despite negative global trends for Russian oil and gas companies, the share of imports in this area remains high, especially in the field of innovative technologies that have found application when working with hard-to-recover reserves, hydraulic fracturing and direct production on the shelf.

Despite the signed agreement with OPEC +, no one is going to stop oil and gas production, and this is impossible, but experts and company owners agree with it - the need to modernize the industry. It is necessary to pay more attention to the development of small fields and fields with hard-to-recover reserves, which in the end can bring significant profits: up to 30-35 billion rubles and more than 100 million tons of produced oil [15].

Experts understand the modernization of the industry as the introduction of information technologies and automation of oil refining processes, the use of mathematical models to predict the quality indicators of oil and gas production solely on the basis of laboratory tests and indicators. 
Relevant areas in this area are the creation of models and experimental studies of processes occurring in the natural environment, the development of software for processing and interpretation of geological and geophysical data, and so on. These developments will help in obtaining virtual images of production facilities, which will speed up the process of creating new types of equipment, design and construction.

Innovative technologies have penetrated into the oil and gas industry, which have affected the production and sale of energy carriers. Analysts have proven the need to use monitoring technologies for both downhole equipment and surface infrastructure facilities. The ability to monitor the results of monitoring in real time allows you to respond in a timely manner to all kinds of technological changes that may lead to accidents and failures.

The oil and gas industries today have set themselves the task of a technological breakthrough associated with the introduction of technologies to increase productivity through 3D / 4D geomechanical and physicochemical modeling. Among large companies such as Rosneft, the target strategy for 2022 states that in order to achieve the set goals for increasing productivity, it is necessary to apply digital technologies and new industrial standards. In order to better navigate this problem field, Rosneft signed an agreement with General Electric on the intentions to create an enterprise that implements new technologies for optimizing, collecting, processing and analyzing data.

\section{Conclusions}

The end of 2019 and the beginning of 2020 turned out to be one of the most difficult for the oil and gas industry of the Russian Federation. An 8\% drop in oil production has looked almost catastrophic over the past eight years. All this happened against the backdrop of a deteriorating situation in the global gas market, where gas production similarly decreased by $8 \%$. Unfortunately, the export of energy resources under the Power of Siberia project to China is also lagging behind the planned indicators.

The improved environmental situation in several regions of the world due to the pandemic stimulates the process of electric mobilization. For TNCs, net importers of oil from the European Union, Japan, and Korea, this is a potential source of economic growth. European majors - BP, Equinor, Shell, Total - have set decarbonization goals, transforming from oil and gas into diversified energy companies.

Today Russian companies are in a rather difficult position, which, on the one hand, is due to the need to search for new deposits and new ways of processing raw materials to achieve a more competitive status; on the other hand, companies must understand the further directions of their development associated with the introduction of new digital technologies.

Russian oil and gas companies need to refer to the experience of foreign companies. The largest oil and gas companies are actively acquiring startups in the field of artificial intelligence. For example, GE and Statoil have jointly invested in Ambyint.Saudi Aramco has invested in Earth Science Analytics, a startup developing the next generation of artificial intelligence software for oil and gas science. BP has invested in Belmont Technology, a startup looking to empower the company in artificial intelligence and digital technologies in its offshore exploration business. Shell, Saudi Aramco and Chevron have jointly invested in artificial intelligence startup Maana, which has partnered with Microsoft on its Azure cloud computing platform.

Thus, the oil and gas companies of the Russian Federation must, on the one hand, rethink the strategies of cooperation and interaction with universities, and on the other hand, switch to an ecosystem approach in production. As for the energy sector, with the help of innovative technologies it is possible to achieve highly efficient, energy efficient, resource-saving and geoecological production. This policy entails the search for new oil 
and gas fields, which will subsequently lead to an increase in the recovery factor of reserves, will be reflected in the depth of processing of raw materials, and will naturally lead to a decrease in losses not only during production, but also during transportation.

\section{References}

1. Gatto, A. An extensive data set on energy, economy, environmental pollution and institutional quality in the petroleum-reliant developing and transition economies [Electronic resource] // Data in Brief Available online, 17 January, 2021 Rezhim dostupa: https:// sciencedirect.com/science/article/pii/S2352340921000500\#tbl0001 (data obrashchen 24.12.2020).

2. Tagliapietra, S. The impact of the global energy transition on MENA oil and gas producers [Electronic resource] // Energy Strategy Reviews, 26, November, 2019 Rezhim dostupa: https://doi.org/10.1016/j.esr.2019.100397(data obrashchen 24.12.2020).

3. Alotaibi, M.N. Crude oil price and private sector of Saudi Arabia: Do globalization and financial development matter? New evidence from combined cointegration test [Electronic resource] // Resources Policy. 69, 2020 December Rezhim dostupa: https://doi.org/10.1016/j.resourpol.2020.101774(data obrashchen 25.12.2020).

4. Yildirim, Z., Arifli, A. Oil price shocks, exchange rate and macroeconomic fluctuations in a small oil-exporting economy [Electronic resource] // Energy. 219 (15) March,2021. Rezhim dostupa: https://doi.org/10.1016/j.energy.2020.119527(data obrashchen 25.12.2020).

5. Śmiech, S., Papież, M., Rubaszek, M. \& Snarska, M. The role of oil price uncertainty shocks on oil-exporting countries [Electronic resource] // Energy Economics. 93, January 2021. Rezhim dostupa: https://doi.org/10.1016/j.eneco.2020.105028(data obrashchen 24.12.2020).

6. Serletis, A. Oil prices shocks and the Russian economy [Electronic resource] // The Journal of Economic Asymmetries 21, June,2020. Rezhim dostupa: https://doi.org/10.1016/j.jeca.2019.e00148 (data obrashchen 25.12.2020).

7. Guo,Y., Yang,Y. \& Wang,C. Global energy networks: Geographies of mergers and acquisitions of worldwide oil companies [Electronic resource] // Renewable and Sustainable Energy Reviews. 139, April,2021. Rezhim dostupa: https://doi.org/10.1016/j.rser.2020.110698(data obrashchen 26.12.2020).

8. Recalde, M.Y. Which aspects may prevent the development of energy service companies? The impact of barriers and country-specific conditions in different regions [Electronic resource] // Energy Services and Management,2021.-293-315 Rezhim dostupa: https://doi.org/10.1016/B978-0-12-820592-1.00013-0 (data obrashchen 26.12.2020).

9. Longxin, M. U., Zhifeng, J. I. Technologcial progress and development directions of PetroChina overseas oil and gas exploration [Electronic resource] // Petroleum Exploration and Development. 46(6), December,2019 Rezhim dostupa: https://doi.org/10.1016/S1876-3804(19)60265-X(data obrashchen 26.12.2020)

10. World Development Indicators [Electronic resource] // Rezhim dostupa: https://databank.worldbank.org/source/world-development-indicators (data obrashchen 25.12.2020) (in Russ.) 
11. Eurostat-OECD PPP Program 2021. [Electronic resource] // Rezhim dostupa:. https://www.worldbank.org/en/programs/icp (data obrashchen 26.12.2020) (in Russ.)

12. database CPIA 2021 [Electronic resource]// Rezhim dostupa: https://datacatalog.worldbank.org/dataset/country-policy-and-institutionalassessment (data obrashchen 26.12.2020) (in Russ.)

13. U.S. sanctions help Russia boost oil exports in 2019. [Electronic resource] // Forbes Rezhim dostupa: https://yandex.ru/turbo?text=https\%3A\%2F\%2Fwww.forbes.ru\%2Fnewsroom\%2Fbiz nes\%2F391643-sankcii-ssha-pomogli-rossii-uvelichit-eksport-nefti-v-2019-godu (data obrashchen 26.12.2020)

14. Finansovo promyshlennye grupy 2021[[Electronic resource] // Rezhim dostupa: https://www.investmentrussia.ru/finansovo-promyshlennye-grupy/( data obrashchen 27.12.2020) (in Russ.)

15. Dylevskaya, A. I., Avilova, V. V. Strengthening the role of small oil companies in the Russian Federation [Electronic resource] // Rezhim dostupa: https://cyberleninka.ru/article/n/usilenie-roli-malyh-neftyanyh-kompaniy-vrossiyskoy-federatsii (data obrashchen 27.12.2020) (in Russ.)

16. Bondar, A. Due to US sanctions, Europe began to actively buy expensive Russian oil [Electronic resource] // European News. Rezhim dostupa: https://replyua.net/europe/143005-iz-za-sankciy-ssha-evropa-nachala-aktivnopokupat-doroguyu-rossiyskuyu-neft.html. (data obrashchen 28.12.2020) (in Russ.)

17. Ivanov, R. hree scenarios of the development of the world energy industry until 2050 - experts [Electronic resource] // 365 Info. Rezhim dostupa: https://365info.kz/2017/06/tri-stsenariya-razvitiya-mirovoj-energetiki-do-2050-godaeksperty. (data obrashchen 25.12.2020) (in Russ.)

18. Five of the leading oil and gas companies in Russia [Electronic resource] // Rezhim dostupa: $\quad$ https://oilcapital.ru/article/general/30-06-2020/pyaterka-veduschihneftegazovyh-kompaniy-rossii (data obrashchen 28.12.2020) (in Russ.)

19. To drill or not to drill [Electronic resource] // Rezhim dostupa: https://www.finam.ru/analysis/forecasts/to-drill-or-not-to-drill-rossiiyskiiy-neftegaz-v2020-godu-20201111-16390/( data obrashchen 26.12.2020) (in Russ.) 